\title{
Miranda
}

Revue pluridisciplinaire du monde anglophone /

Multidisciplinary peer-reviewed journal on the English-

speaking world

$14 \mid 2017$

Early American Surrealisms, 1920-1940 / Parable Art

\section{Visiting the Highest Heaven: Gender-Free Narration and Gender-Inclusive Reading in Olive Schreiner's Dreams (1890)}

\author{
Nathalie Saudo-Welby
}

\section{OpenEdition \\ Journals}

Electronic version

URL: http://journals.openedition.org/miranda/9881

DOI: 10.4000/miranda.9881

ISSN: 2108-6559

\section{Publisher}

Université Toulouse - Jean Jaurès

\section{Electronic reference}

Nathalie Saudo-Welby, "Visiting the Highest Heaven: Gender-Free Narration and Gender-Inclusive Reading in Olive Schreiner's Dreams (1890)", Miranda [Online], 14 | 2017, Online since 04 April 2017, connection on 16 February 2021. URL: http://journals.openedition.org/miranda/9881 ; DOI: https:// doi.org/10.4000/miranda.9881

This text was automatically generated on 16 February 2021.

\section{cc)}

Miranda is licensed under a Creative Commons Attribution-NonCommercial-NoDerivatives 4.0

International License. 


\title{
Visiting the Highest Heaven: Gender-Free Narration and Gender- Inclusive Reading in Olive Schreiner's Dreams (1890)
}

\author{
Nathalie Saudo-Welby
}

1 Olive Schreiner (1855-1920) was a South-African essayist, short story writer and novelist committed to the cause of female emancipation and pacifism. ${ }^{1}$ Her first and best-known novel, The Story of an African Farm (1883), set in her native South Africa, was the first of a sub-genre of feminist novels exploring the thoughts and life of the "New Woman"2. The heroine, named after Schreiner's mother's last name, Lyndall, is a great speaker. In her long feminist speeches, addressed to her meek friend Waldo, she expresses her contempt for female schooling and traditional marriage arrangements. Having refused to marry her child's father, she dies in near-solitude in an inn in the South African countryside. The novel contains a great variety of discursive forms, including two parables. "Times and Seasons" (Part II, Chapter 1) tells the story of a soul from infancy to death. The second allegory, told by a character called "Waldo's Stranger" (Part II, Chapter II) and incorporated into Schreiner's Dreams seven years later as "The Hunter", recounts a quest for Truth involving disillusionment, renunciation and asceticism, which are recurrent features of her tales of human improvement.

2 Throughout her writing career, Olive Schreiner manifested a constant interest in allegory. ${ }^{3}$ In a letter to the writer and editor Ernest Rhys, she wrote that "by throwing a thing into the form of an allegory [she could] condense five or six pages into one, with no loss, but a great gain to clearness" (Letters 136). At the time, in the early 1890s, Schreiner was working on her two major collections of allegorical short stories, Dreams (1890) and Dream Life and Real Life (1893). ${ }^{4}$ They were the outcome of her research and reflection on the "sex question", which she felt it her duty to examine for, she wrote, "[t]here is no side of the sex question, woman's intellectual equality (or as I hold, 
inequality with man), marriage, prostitution, in which one has not to speak" (Letters 136). ${ }^{5}$ In her partly autobiographical novel From Man to Man, on which she worked throughout her life and which was published posthumously in 1926, one finds a description of the process and advantages of writing allegories. Rebekah, the character with the writing capacities and taste, is a pregnant mother of three who is constantly interrupted by daily chores, and her writing is described as a disjointed and rambling process. Rebekah writes down her allegories after a long period of theoretical reflection ${ }^{6}$ which crystalizes into a vision that eventually develops into a draft-version of the work to come. Her creative process unfolds in three stages: first thinking out loud, then walking around her desk and finally writing. Her "scribbling"7 results in an accumulation of unpublished material consisting of short stories, "little allegories told in rhyme" and "one very long allegory in blank verse, which was never quite finished" (From Man 176). The narrative voice offers the comment that Rebekah is unlikely to return to this last piece in the future because "it takes time to write things for other people" (225). Schreiner thus seemed to conceive of allegories as a painstaking, selfless enterprise of didactic intent.

Olive Schreiner's feminist allegories constitute a rich source for a narratological inquiry into the ways in which perceptions and constructions of gender can be challenged. As Maureen Quilligan has shown, allegory works by narrativizing and projecting horizontally a situation, thus problematizing the vertical categories on which it relies: its underlying ideological assumptions.

Allegory tames a reader's impatience by insisting on its own paratactic leisure to unfold, manipulating the reader's responses by continually tempting him, but never allowing him to make final vertically arranged statements about the significance of what he has read. (Quilligan 236)

The use of the generic masculine (as here) to designate a single, universal reader is one such assumption. As Elizabeth Jay notes in her introduction to Dreams, Schreiner's use of an androgynous voice can be perceived as an attempt "to ward off the dangers of her visions being read as specifically female” (Schreiner, Dreams xx) but Schreiner's genderindeterminate allegories also demonstrate the ways in which feminist writing can question and challenge our usual manner of interpreting stories about women. I will not be considering whether Schreiner's writing can be described as feminine, nor will I try to evaluate whether the narrative voice is feminine. I mean to contribute to feminist narratology by showing how feminist allegorical thinking impacts on gender markers and on the construction of the narrative voice. In his defense of intercultural narratology, Ray Somner has pointed out the cultural and human agenda behind narratology:

(...) narratology has a didactic purpose and even a utopian dimension: It proceeds from the assumption that fictions allow readers to develop a sensitivity for intercultural conflicts and misunderstandings, and it remains dedicated to [the goal of] fostering and promoting intercultural understanding. (Somner 77)

This intercultural understanding works by testing narratological models against existing gendered, class or racial representations, so as to create a culturally-conscious form of poetics. ${ }^{8}$ Schreiner's engagement with issues of race and gender in the allegorical form calls for a contextualized narratology that might cast light on her minute departures from common and expected textual practices and patriarchal standards. Gender is represented literally in the allegories, and gender-difference is a powerful argument in them, but a close analysis of the collection's narrative structure 
shows that, as we move from stories told in the third-person to stories told by firstperson agents of ambivalent or oscillating gender, we progress perceptibly from gender-assertiveness to gender inclusiveness. I will first examine how Dreams obeys a three-part structure which brings the reader ever closer to gender undifferentiation. I will then use the literature on Schreiner's Dreams as a kind of survey of how readers negotiate the neutrality or ambivalence of first-person narrators. Finally I will make a case for a gender-inclusive reading of Dreams, based on an awareness of what constitutes gendering and an alternation of gender positions.

\section{The narrative structure of Dreams}

Being the daughter of a Lutheran missionary, Schreiner knew the Bible well, and wrote her allegories in simple Biblical language. ${ }^{9}$ The stories in Dreams consist in dream visions, half of which are structured as follows: in a frame narrative, a first-person narrator falls asleep, has a dream, wakes up, falls back to sleep and has another dream... In the embedded dreams, the narrator-questor meets a guide-interpreter, in the form of God himself, an angel or more vaguely "one beside me" (16), who helps him/her interpret the vision, or takes him/her on a tour of Heaven and Hell. ${ }^{10}$ The interpreter occasionally comments orally on the scene for the dreamer's benefit. Each story achieves some kind of transformation in a character or closes with a revelation, but no clear moral is ever formulated at the end, and despite the presence of an interpreter, the reader is often left to wonder what point the author was trying to make.

7 Schreiner's initial subversion of the form of the allegorical quest is to substitute a narrator of undecidable gender for the traditional male hero-questor. ${ }^{11}$ In the sparse, impersonal form of the allegory, Schreiner, who published her first works under the pseudonym Ralph Iron and included a scene of cross-dressing in the chapter entitled "Gregory's Womanhood" in The Story of an African Farm, found new ground for experimenting with gender trouble. Her allegories combine three gender-nonspecific strategies: narration in the first-person singular, the first-person plural and the second person. ${ }^{12}$ Occasionally, the narrator's gender is only specified unobtrusively in the course of the narrative.

Research on Dreams has shown that race, age and gender are interchangeable and often inseparable in Schreiner's writing (Chrisman) ${ }^{13}$ Yet, in Dreams, gender is generally represented literally: even when the characters in the allegories are left nameless, and are clothed in unisex "mantles" or "robes", they are nearly always clearly identified as a man or a woman. There is no attempt to substitute, in allegorical fashion, something "other" for gender difference. The guide-interpreter frequently answers questions about the characters' sexual identity and gender is sometimes the allegory's main theme (in "Three Dreams in a Desert", for instance). Since even some values and inanimate elements are gendered, gender binaries are reinforced but the constructed and cultural nature of gender attribution is also foregrounded: Reflection is called a "strange old woman" (4); Life and Truth are female; Love and Duty are male; Joy and Sympathy are initially neutral (it), and occasionally male (he). In the final words of "Three Dreams in a Desert", the sun is male: "Then the sun passed down behind the hills; but I knew that the next day he would arise again." (21) 
In spite of this explicitness, some of Schreiner's allegories also build up a rarefied space where gender barriers are effaced. The angel in "In a Ruined Chapel" can "unclothe a human soul", "take from it all those outward attributes of form, and colour, and age, and sex, whereby one man is known from among his fellows and is marked off from the rest" (27). The last story in Dreams presents the "highest" Heaven as a sex-free place where God's creatures, having shed their accidental earthly attributes, become androgynous. Their souls become one great whole, unmarked by sex, color or age. This state of sexual and intellectual undifferentiation is shared by the observed and the observer since in the "highest" Heaven, people no longer "see things separately" (45).

Then we came out upon a lonely mountain-top.

No living being moved there; but far off on a solitary peak I saw a lonely figure standing. Whether it were man or woman I could not tell; for partly it seemed the figure of a woman, but its limbs were the mighty limbs of a man. I asked God whether it was man or woman.

God said, "In the least Heaven sex reigns supreme; in the higher it is not noticed; but in the highest it does not exist." (44)

While in this state of enlightenment, the narrator has glimpses of a world in which distinctions of sex, race and class no longer exist; however, of the three, it is the distinction of sex that seems to be the most important. By holding up the utopian vision of heavenly androgyny in this final allegory, Schreiner is making a statement about the accidental quality of sex, the equal value of human lives and their spiritual nature; she is also bringing to an end the discords between man and woman which are dramatized in other dreams: domination, jealousy, self-sacrifice, accusation and indifference. At that point, the narrator of uncertain gender is both the subject of the utopian vision - a visionary - and the object of the utopian vision. The use of a firstperson narration - which, in English, allows the gender of the narrator to remain unidentified - places undifferentiation right at the heart of the text, and of the universe it promises.

11 The transformative power of Dreams can be felt developing throughout the volume. As one reads through the succession of stories, the narrators undergo a significant, albeit unsystematic, evolution from neutrality to gender-inclusiveness. In narrative terms, Dreams falls into three parts (which I will separate for the sake of clarity). The first four stories are told in the third person and present clearly gendered characters and gendered values (section I). The following stories (section II) are almost all told in the first person, a narrative technique which allows the writer great gender latitude, since grammatical gender is not marked in English. In Part II, five stories are told by a firstperson narrator who remains neutral throughout, thus creating a major mode of gender neutrality; two stories, written in the third person, stand as exceptions. The last two stories in the collection (section III) are told by a first-person narrator who becomes gendered in the course of the narrative. In the last but one story, "I Thought I Stood", the narrator proves to be female, while in "The Sunlight Lay Across my Bed", the dreamer turns out to be male. In section I, gender is specified and unproblematic. In section II, gender is problematic and unspecified. In section III, gender is problematic and ambivalent.

12 Love and sex relations are important themes in the stories. The personified, gendered values in the first story, "The Lost Joy", an allegory of love, convey the sense of unproblematic heterosexual love, thus setting it as the default mode of the stories. The second and third stories are symmetrical in so far as their main characters (a man in 
the first of them, a woman in the second) are both confronted to gendered values (he to the female bird of Truth, she to male Duty). The fourth story, "In a Far-Off World" opposes "a woman" and the man she loves. While there is no doubt in these first stories about the gender identity of the characters and their values, the same is not true of the narrators in the following stories (sections II and III). Since the earlier stories have imposed a binary frame within which to think about the narrator's gender, it seems to be more appropriate to call the narrator "gender free" or "gender-unmarked" than "gender-neutral", for the reader is made to envisage each of the two possibilities in turn rather than dismiss the issue by calling the narrator "neutral". When the narrator's gender is specified in the course of the narrative, I will call it "ambivalent", because the use of a single marker cannot invalidate the interpretative work that has been accomplished earlier. The initial ambiguities of the text are not entirely redeemed or resolved by the signs that follow. Dreams thus appears to be a fine illustration of Umberto Eco's conception of the "open work", whose appreciation is predetermined but not limited by the author's intentions.

[T] he form of the work of art gains its aesthetic validity precisely in proportion to the number of different perspectives from which it can be viewed and understood. (...) A work of art, therefore, is a complete and closed form in its uniqueness as a balanced organic whole, while at the same time constituting an open product on account of its susceptibility to countless different interpretations which do not impinge on its unadulterable specificity. Hence, every interpretation is both an interpretation and a performance of it, because in every reception, the work takes on a fresh reception for itself. (Eco 3, 4)

The idea that any interpretation is a performance partly originates from the exemplary openness of musical compositions, which require both an interpreter and a listener, and in particular of modernist "works in movement". It remains singularly relevant in our case, if we accept Judith Butler's contention that gender is a kind of performance. Reading a first-person narrative is one of the many different modalities in which one enacts gender, understood as a form of subjectivation and identification in response to a set of constraints.

\section{The gendering of the narrator}

14 When the stories are told in the first person, the readers are left to replace the narrator's gender with their own, or to infer the narrator's gender, using the context or subjective reasons. However, the knowledge that the author is a woman is bound to influence the attribution of gender to the narrator. In her Introduction to Narratology (2009), Monika Fludernik writes:

\footnotetext{
Nowadays most narratologists would acknowledge the fact that readers regularly perceive narrators, especially first-person narrators, but also authorial narrators, as being gendered either male or female, even if they are not explicitly labeled as men or women. In this implicit attribution of gender, which is historically and culturally conditioned, the biological sex of the novel's author is highly significant; so are the narrator's style and the level of politeness of her/his verbal interaction with the narratee or implied reader. (Fludernik 69)
}

In an earlier article, "The Genderization of Narrative", Fludernik drew on the results of a survey of readers of stories told by first-person narrators of unspecified gender to elaborate a typology of unambiguous and ambiguous textual clues. Her "ironic" conclusion is that the texts which ambiguate gender attributions depend on the readers 
to test their hypotheses against "the worst (and most naïve) kinds of cultural clichés" (169), thereby reinforcing them. In her essay "Queering Narratology", which focuses on Written on the Body, Jeanette Winterson's novel-size experiment with a sexually unmarked first-person narrator, Susan Lanser writes:

Not all autodiegetic narratives mark the narrator's sex explicitly; names, clothing, and physical attributes - characteristics of gender - do indeed (...) allow or encourage readers to construct assumptions about a narrator's sex. (Mezei 253)

However, the lack of realism and sparseness of Schreiner's allegories hinders the construction of such assumptions. The ambivalence of sex markers and the elusiveness of gender clues bring her collection of stories close to Winterson's queered narrative.

It is not certain to what extent Schreiner essentialized the gender specificity of values by gendering them. The list of examples given above can also be taken to question traditional associations rather than confirm them. Readers assign gender by trying to infer the character/narrator's sex, depending on how they respond to the characters and narrators ideologically, but also according to their own desires ${ }^{14}$ In what follows, I have reviewed the work of writers on Schreiner's Dreams in search of their genderconscious responses to her gender-elusive narratives.

How do individual readers negotiate the attribution of gender and how do their choices impact on the overall interpretation of the allegory? Earlier scholarship on Dreams yields conflicting results. ${ }^{15}$ Laura Chrisman writes of the narrator of Dreams in general terms as having "a mediatory position in relation to the action she perceives." (Chrisman 127; emphasis mine) Her essay however points to the way Schreiner "slides into grammatical ambiguity" when describing the subjectivity of the African woman.

It stands as a revelation of the degree to which Schreiner's own unconscious is colonized and colonial: her very conceptualization of (or inability to conceptualize) the origins of her own psyche inevitably takes the route of African otherness. (...) The force of repression and the force of emancipation are difficult to distinguish, and this is where Schreiner's theory stops, with an impasse produced by a fear of the unconscious that is equal to Schreiner's fear of rationality. (Chrisman 139)

Schreiner's interrogations lead to an ambivalent representation of the boundaries of identity. Having drawn a distinction between Bertolt Brecht's and Judith Butler's concepts of performance, Scott McCracken chooses to read two of the stories as performances of New Woman subjectivity. Commenting on the indeterminate gender of the narrator in "Three Dreams in a Desert", he notes that "[t]he plurality of male figures and the undecidability of the narrator's gender mark a refusal to essentialise gender positions." (236) In her detailed analysis of the same story, Ann Heilmann accounts for her own process of gendering:

Though never clearly defined, the narrator's gender can be presumed to be female: her passionate empathy with the protagonist of the dreams suggests that this woman represents aspects of her own experience, and both women, by virtue of being juxtaposed with a male authority figure, are aligned with Emotion (the Heart) in a binary opposition which ascribes Reason (the Head) to an old man. (Heilmann 127) ${ }^{16}$

Ann Heilmann considers that an interpretation of the story involves the conscious process of attributing a sex to a fictional persona, and she traces her own process of weighing the different categories which construct our perceptions of gender, and which the allegorical form sets out to question. 
21 The last and longest story in the collection, "The Sunlight Lay Across my Bed", is framed by a narrative in which the narrator, who is lying alone in bed at night, can hear the sounds of what must be the night life of London's East End, falls asleep and dreams that God shows him/her around Hell. At the end of the tour, the dreamer expresses his/her desire to go back to earth, wakes up, falls back to sleep and is shown around Heaven. In the morning, the narrator wakes up, immediately falls back to sleep, before waking up for good with relief: "the long day was before me" (46). In The Healing Imagination of Olive Schreiner, Berkman perceives the narrator as male, without making any particular comment about how she reached that conclusion (Berkman 1989, 214). She notes the "transformative" power of the dream since the narrator awakens to a radiant London, in a more hopeful mood. About a few lines in the same story ${ }^{17}$, McCracken writes:

[It] seems to start where "Three Dreams" leaves off, but the title directs the African Sun into the heart of the metropolis. The bedroom constructs a feminine position by context rather than through an identifying pronoun, evoking what Schreiner called in Woman and Labour, "sex parasitism": middle-class women's dependence on men for support and their reduction to a purely sexual function. The narrator is placed in relation to the discipline of the city: "the policeman's beat on the pavement"; structures of class and gender, "the wheels of the carriages roll home from houses of entertainment"; and, with the "woman's laugh below my window", against the other women who work in those houses. (McCracken 237)

For cultural and subjective reasons, McCracken considers that the dreamer is female. However, at this particular moment in the narrative, I cannot help perceiving the narrator as male, perhaps because I am reluctant to associate the voice of Schreiner, who later wrote on prostitution in From Man to Man, with a woman coldly listening to the laughter of a fallen fellow-woman. My own reading of the same lines is that the narrator's situation and sensations constitute a vignette of London's East-End night-life, familiar to readers of late-nineteenth-century Gothic fiction. The narrator's impressions are reminiscent of those of several fin-de-siècle male degenerates. I am reminded of Dorian Gray overhearing the "[w]omen with hoarse voices and harsh laughter", or the "woman in a ragged shawl (...) stumbl[ing] away, laughing" and "the slow heavy tread of the policeman" in the London streets at night (Wilde 215, 263, 264) in the same year. ${ }^{18}$

23 At the start of the dream, the narrator contemplates joining a group of "women" who bite into the fruit from the tree of knowledge, then joining some "men" who are working among the trees (34). The inevitable hesitations and disagreement about the narrator's sex prove how finely Schreiner's style has maintained the ambiguity. Ten pages later however, the narrator's neutrality is brought to an end:

And one from among the people came running towards me [neutral]; and when he came near it seemed to me that he and I had played together when we were little children, and that we had been born on the same day. And I told God what I felt; God said, "All men feel so in Heaven when another comes towards them."

And he who ran towards me held my hand, and led me through the bright lights. And when we came among the trees he sang aloud, and his companion answered, and it was a woman, and he showed me to her. She said, "He must have water"; and she took some in her hands, and fed me [male] (I had been afraid to drink of the water in Hell), and they gathered fruit for me, and gave it me to eat. They said, "We shone long to make it ripen," and they laughed together as they saw me eat it.

The man said, "He is very weary; he must sleep" (for I had not dared to sleep in Hell), and he laid my head on his companion's knee and spread her hair out over 
me. I slept, and all the while in my sleep I thought I heard the birds calling across me. And when I woke it was like early morning, with the dew on everything. (41-42; emphasis and commentaries mine) the stage of interpretation. Response to the text will thus vary according to the type of reader. The casual reader might overlook some of the linguistic signs of the narrator's gender or the absence of markings, and experience, unaware, a form of gender fluidity. The gender-conscious reader will make his/her own informed contextualized choices and avoid re-injecting elements of essentialism. The careful reader will refuse to assign one sex or the other unless grammatically forced to do so. In such a case, his/her interpretative task will consist in performing both identities in turn, the openness of the work resulting in a plurality of interpretations. "To the extent that sex and gender matter for interpretation, the nonmarking of sex yields, in some sense, two narrative texts", Susan Lanser writes. "Moreover, the narrative opens 
questions about the relationship between sex and gender in ways which allow the reader to test his or her own assumptions repeatedly." (Mezei 255) I will now follow Judith Butler's invitation to "perform" gender and play the part of such a reader in a three-phase gender-inclusive approach.

\section{A gender-inclusive reading}

The dramatized structure of the stories results in the dreamer becoming the spectator and interpreter of his/her own dream. This figure is also a mise-en-abyme of the reader. When identifying with this every/wo/man, the reader of either sex shares the dreamer's need to interpret the dream. The genderless narrator and the genderindeterminate creatures contribute to the construction of the highest Heaven and to establishing an ideal which Schreiner took to heart: the sister-brotherhood between men and women. This happens when couples are formed, but it also occurs when the narrator - and hence the reader - need to decide which side to take in quarrels between men and women. The English language and the abstraction of the allegorical form allow Schreiner to create a space free of gender bias, a space which only has a virtual existence in the interpretative act. The reader is then free to share in the narrator's gender indeterminacy and confirm God's saying that those who have caught sight of heaven should go back to the earth for "that which [they] seek is there" (46). The loop comes full circle. The dreamer's state and the reader's function are the closest one can get to heaven. In this process, Schreiner plays the part of the angel who is able to "unclothe a human soul" (27) by taking off what forms its accidental identity, such as gender.

In "Three Dreams in a Desert", a story Schreiner wanted "every woman in England to read" (Letters 138), the narrator witnesses how man has maintained woman in a state of subjection: "The oldest, oldest, oldest man living has never seen her move" (16). S/He then learns how woman can rise. As the only noticeable difference between the two creatures is that they happen to be called "man", "woman", "he", or "she", the injustice of the scene becomes glaringly evident. Although the dreamer does not express any feelings, one can guess by his/her questions that $\mathrm{s} /$ he disapproves. There can be no hesitation about which "side" to take when witnessing such arbitrary oppression. Yet, $\mathrm{s} / \mathrm{he}$ is likely to adopt the female and male gender in turn through a sort of mental conversion. She will experience solidarity with her sister woman; he may do so. He may experience shock or guilt when realizing the extent of woman's sacrifice; she might be fueled by the spirit of revolt which Schreiner tried to arouse in women. The dreamer's indeterminate sex maximizes the emotional impact of the scene. By accepting gender leeway and taking on alternative gender identities, the reader multiplies rather than narrows the possible interpretations.

30 A gender-free narrator is also less accusatory. In the story entitled "I thought I stood", God condemns the idea that women should come to him to "arraign" men (31), and encourages women to go back to man and talk it out. The allegories are indeed interdependent, one shedding light and relativizing the meaning of the other. Taken separately, they illustrate Susan Suleiman's proposal that "there is no such thing as a story that "expressly entails a meaning"' (Suleiman 43). They indeed constitute their own intertext, where gender is alternatively essentialized or problematized. 


\section{Dreams as intertext} gender distinctions. Neutral narration or total androgyny would have deprived some of Schreiner's allegories of their meanings. Just as heaven is said to be "one" only to be described as having several levels and several doors (40), one cannot make sense of a great blended totality and there needs to be sexual difference in order for Schreiner to drive her arguments home. Before we learn that the dreamer of "The Sunlight Lay Across my Bed" is male, God shows him creatures who are shining on plants so that they may grow. "Shining", which can be taken as nurture, breeding, education, or creation, is presented as a male and female joint activity.

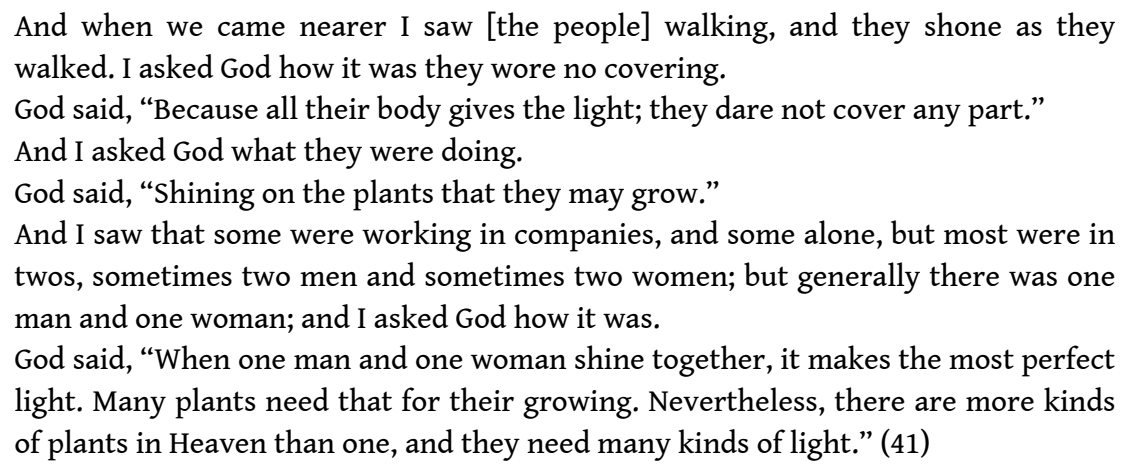

This passage is typical of Schreiner's oscillations. The allegory goes through three argumentative stages: God's creatures first shine either separately or in pairs, either in same-sex couples or in mixed couples. When the unprejudiced narrator expresses his/ her surprise at the prevalence of mixed couples, God answers that each sex sheds a different light, and Schreiner introduces the idea of a complementarity between the male and female sexes, thus suggesting the perfection of heterosexual creation and production. When God goes on to say that plants may grow under different conditions because "there are more kinds of plants in Heaven than one, and they need many kinds of light," Schreiner seems to be stepping back and taking the edge of what she has just asserted, shifting the emphasis away from the quality of the light to the nature of the plant. Schreiner's rhetorical maneuvering proves that differentiation is necessary to logical and allegorical thinking. Having shifted from the difference of sex to the product of a relationship between the sexes ("perfect light"), she moves from what is given - the light - to what receives it: the plant. She decides not to be more specific about the nature of the plant, but she could have done so had she chosen to. Maureen Quilligan's insistence that the apparent verticality of allegories is transcended by the reader's need to "become aware (...) of the way he reads the text" (Quilligan 28) is corroborated by this case of potentially sprawling distinctions.

The sexual essentialism which pervades nineteenth-century feminist writing and has infuriated twentieth-century feminists often serves argumentative purposes rather than thematic ones. Arguing in favor of equality produces allegories of undifferentiation whereas arguing in favor of female productivity and sex complementarity produces allegories of differentiation. The vision of same-sex creatures doing fruitful creative work together tends to prove that Schreiner established a clear distinction between biological sex and gender, and that her thinking of female identity is detached from that of procreative sexuality. 
Recent readings of New Woman fiction have emphasized the instability of writers' strategies, usually attributing it to their multiple, inconsistent agendas (Heilmann). In Schreiner's case, too, it may have been her choice not to remain fully in control of the dreamer's gender but to surrender part of her authority over the text. According to this interpretation, Schreiner's control over the creative process extends to the act of surrendering control over the dreamer's gender. In other words, genderlessness is a stylistic accomplishment, a semantic gain and a mark of gender-awareness. Schreiner's Dreams allegorizes her own critical thinking about gender: one should consider that sex reigns supreme in this world, change things so that it does not limit people's possibilities, while trying to envision a utopian world where it does not exist. "[S]ee[ing] things separately" (45) is a rhetorical and political necessity; thinking in terms of oneness is a philosophical necessity.

\section{Does God make slips of the tongue?}

In The Story of an African Farm, a novel which mixes a vast range of different textual practices, the allegory contained in the chapter entitled "Times and Seasons" follows the growth of a soul and its tumultuous relationship with God. The narration in the first person plural blurs the origin of the voice. ${ }^{20}$ Is the omniscient narrator speaking? Is this voice relaying Waldo's reflections? Some expressions like "emasculated" (108) and "wicked boy" (112) inflect the meaning towards the masculine fate. The story being full of references to the Karoo, it must also be partly autobiographical. ${ }^{21}$ Hence, the collective "we" fulfills different functions: establishing a general truth, erasing gender difference, transcending personal experience and allowing for greater reader identification. In this context, it is less surprising that, in a passing reference to the Arabian Nights, "Alladeen" ${ }^{22}$ is gendered female (117). This slippage adds an element of gender-inclusiveness to this abstract tale of the soul's progress.

Schreiner described her creative practice and particularly the writing of Dreams as a long unfruitful process interspersed with outbursts of writing. ${ }^{23}$ So it is not clear how far these details and nuances are premeditated, how far simply slips. The gender latitude they exhibit may be evidence that Schreiner was voluntarily abandoning full control of her writing.

In "The Sunlight Lay Across my Bed", the androgynous creature met by the narrator in the "highest" Heaven is initially designated by the pronoun "it". But, as God takes the narrator back within sight of Heaven and Hell, God calls the creature a "he".

I said, "What has it for all its labour? I see nothing return to it."

Then God touched my eyes, and I saw stretched out beneath us the plains of Heaven and Hell, and all that was within them.

God said, "From that lone height on which he stands, all things are open. To him is clear the shining in the garden, he sees the flower break forth and the streams sparkle; no shout is raised upon the mountain-side but his ear may hear it. He sees the crown grow and the light shoot from it. All Hell is open to him. He sees the paths mount upwards. To him, Hell is the seed ground from which Heaven springs. He sees the sap ascending." (45; emphasis mine)

Either God is guilty of androcentricity in an act of gendering which repeats his biased creation of Adam, or Schreiner failed to produce the heaven she promised by unwittingly falling back on a masculine form to describe something that is neutrally gendered. This conclusion concurs with the closing stage of Laura Chrisman's 
chronological analysis of Schreiner's Dreams, in which, analyzing the images of the crown and diamonds, she shows that the last allegory culminates in "the most extreme example of domination and exploitation extant" and "[ $t$ ]he allegories are not the less important for the impasse they enact" (Chrisman 148).

The glimpse which the narrator is able to get of the androgynous creature is not the climax of his visit however, for, a few lines later, God's light grows so intense that the narrator becomes unable to tell things apart. The capacity to overcome binary oppositions is presented as an ideal state, orchestrated by heavenly music.

And the face turned from its work, and the light fell upon me. Then it grew so bright I could not see things separately; and which were God, or the man, or I, I could not tell; we were all blended. I cried to God, "Where are you?" but there was no answer, only music and light.

Afterwards, when it had grown so dark again that I could see things separately, I found that I was standing there wrapped tight in my little old, brown, earthly cloak, and God and the man were separated from each other, and from me. (45; emphasis mine)

The counterintuitive association between darkness and discrimination in "when it had grown so dark again that I could see things separately" preserves the age-old positive connotations of allegorical light and provides further justification for Berkman's regret that "despite her penchant for undermining polarities, [Schreiner] never suggested that some blend of the two elements, such as dusk, might serve as a more reflective setting than full light or that dark might hold incomparable truths and beauty." (Berkman 1989, 222) This is all the more surprising as light can be freely graded along a continuous scale. By opposition, grading gender (using words like effeminacy, emasculation, unsexedness, etc.) carried heavily negative connotations in a context marked by ideas of decadence, degenerationist discourse, and New Woman bashing. ${ }^{24}$ In theoretical and allegorical texts, light is associated with the ability to see things clearly and distinguish between similar items. It carries the positive connotations of progress, knowledge and clear-sightedness, and became a classic trope of colonial discourse. Schreiner preserved the positive values of light, but also extended them: intense light blinds you so that you can only perceive one great indistinct whole and thus reach the higher state of undifferentiation. The dreamer is able to close his eyes to what is evident, and look inward. The weak eyes are those that shine the most outward (42). Schreiner also preserves the negative values of darkness to the point of generating a paradoxical situation: darkness is conducive to differentiation whereas light generates blindness to separations. This excursion into the issue of colors and light proves that Schreiner was not so eager to blur binary oppositions. By contrast, her approach to gender appears as progressive and stylistically innovative.

41 Issues of gender identity widen the meanings of the allegories instead of narrowing them. The reproach of essentialism which has often been directed at late-nineteenthcentury New Woman and feminist writers ignores the essential point that gender carries different argumentative values according to the context in which it is used. While Schreiner sometimes finds it convenient to emphasize elements of gender identity, she also envisions an ideal state of genderlessness, where gender no longer matters. In other words, gender needs to be understood in context, and this precludes the possibility of quoting from fictional works as though they were essays in order to assess the degree of feminist consciousness of the author. The degree of essentialism one finds in a text is also related to the gender-inclusiveness of one's interpretation. 

independent of cultural gender stereotypes and hetero/homosexual structures. By evaluating the reader's level of sympathy with each sex in turn, gender-inclusive narration results in an expanded form of cross-gender solidarity rather than sexual preference or identity. In the late-twentieth-century romances analyzed by Fludernik (1999) and Lanser (Mezei), ambiguous gender attribution creates a textual space where sexual identity is problematized and the heterosexual model destabilized. Dreams offers a less obvious break with traditional writing practices, but Schreiner's use of gender indeterminacy leads the reader to change interlocutory positions, thus raising his/her gender-awareness. Gender allocation is presented as an external process: the narrator gives no clue to his/her sex, carries no significant attribute and appears to be naively unaware of gender relations. Gender is allocated sometimes by the narrator, sometimes by God or some other third-person character, but their motivations are not revealed. Gender allocation becomes a game, the rules of which are partly linguistic, which forces the reader to reconsider his/her own position. The distinctions and categorizations on which Schreiner relies make the reader sensitive to the verbal implications of issues of gender. Schreiner's literary practice does not include wordplay but rather puts the reader in a position to gain an increased awareness of the way language habits insidiously enforce gender assumptions, thus forcing the reader to "interpret one's interpretation" (Quilligan 252). As the reader observes his/her failure to interpret the text without performing conscious gender adjustments, s/he has to learn how to read and re-read the text, and realize the political implications of these moves. Quilligan's timid suggestion in The Language of Allegory that "the end of the narrative is not merely to invite interpretation, but to excite belief and action" (Quilligan 220) is given a particularly vivid illustration in Schreiner's Dreams.

\section{BIBLIOGRAPHY}

Ardis, Ann. New Women, New Novels: Feminism and Early Modernism. New-Brunswick: Rutgers UP, 1990.

Berkman, Joyce Avrech. The Healing Imagination of Olive Schreiner: Beyond South African Colonialism. Amherst: U of Massachusetts Press, 1989.

---. Olive Schreiner: Feminism on the Frontier. St Alban's: Eden, 1979.

Bjørhovde, Germ. Rebellious Structures: Women Writers and the Crisis of the Novel 1880-1900. Oslo: Norwegian UP, 1987.

Brandon, Ruth. The Old Women and the Old Men: Love, Sex, and the Woman Question. London: Secker and Warburg, 1990.

Butler, Judith. Gender Trouble. London: Routledge, 1990, 2006.

Case, Alison A. Plotting Women: Gender and Narration in the Eighteenth- and Nineteenth-Century British Novel. Charlottesville: UP of Virginia, 1999. 
Chrisman, Laura. “Allegory, Feminist Thought and the Dreams of Olive Schreiner.” Ed. Tony Brown. Edward Carpenter and Late Victorian Radicalism. Frank Cass, 1990. 126-150.

---. "Empire, 'race' and feminism at the fin de siècle: the works of George Egerton and Olive Schreiner." Ed. Sally Ledger and Scott McCraken. Cultural Politics at the Fin de Siècle. Cambridge: Cambridge UP, 1995.

Cronwright-Schreiner, S.C., ed. The Letters of Olive Schreiner 1876-1920. London: Fisher Unwin, 1924. Burdett, Carolyn. "The Hidden Romance of Sexual Science: Eugenics, the Nation and the making of Modern Feminism." In Sexology in Culture. Ed. Lucy Bland and Laura Doan. Cambridge: Polity Press, 1998. 44.59.

---. The Life of Olive Schreiner. London: Fisher Unwin, 1924.

Eco, Umberto. The Open Work. Tr. Ann Cancogni. Cambridge, MA.: U of Harvard P, 1989.

Emerson, Ralph Waldo. Essays and Lectures. New-York: Library of America, 1983.

First, Ruth and Ann Scott. Olive Schreiner: a Biography. Foreword by Nadine Gordimer. London: Women's Press, 1989.

Fludernik, Monika. Introduction to Narratology. London: Routledge, 2009.

---. “The Genderization of Narrative.” GRAAT 21 (1999): 153-75.

---. Towards a “Natural” Narratology. London/New-York: Routledge, 1996.

Hackett, Robin. Sapphic Primitivism: Productions of Race, Class, and Sexuality in Key Works of Modern Fiction. New Brunswick/New-Jersey/London: Rutgers UP, 2004.

Hamilton, Lisa K. “New Women and ‘Old' Men: Gendering Degeneration.” Ed. Schaffer, Talia and K. A. Psomiades. Women and British Aestheticism. Charlottesville: UP of Virginia, 1999. 62-80.

Heilmann, Ann. New Woman Strategies: Sarah Grand, Olive Schreiner, Mona Caird. Manchester: Manchester UP, 2004.

Horton, Susan R. Difficult Women, Artful Lives: Olive Schreiner and Isak Dinesen, In and Out of Africa. Baltimore/London: John Hopkins UP, 1995.

Kranidis, Rita S. Subversive Discourse: The Cultural Production of Late Victorian Feminist Novels. NewYork: St Martin's, 1995.

Kucich, John. Imperial Masochism : British Fiction, Fantasy, and Social Class. Princeton/Oxford : Princeton UP, 2007.

Lanser, Susan Sniader. Fictions of Authority: Women Writers and Narrative Voice. Ithaca/London: Cornell UP, 1992.

Ledger, Sally. The New Woman: Fiction and Feminism at the fin de siècle. Manchester: Manchester UP, 1997.

Linton, Eliza Lynn. The Girl of the Period and Other Essays. 2 vols. London: Bentley, 1883.

Little, Judy. Comedy and the Woman Writer: Woolf, Spark, and Feminism. Lincoln: U of Nebraska P, 1983.

Madsen, Deborah L. Rereading Allegory: A Narrative Approach to Genre. New-York: St Martin's, 1994.

Mangum, Teresa. Married, Middlebrow, and Militant: Sarah Grand and the New Woman Novel. Ann Arbor: U of Michigan P, 1998.

“Manly Women.” Saturday Review, 22 June 1889: 756-57. 
Marks, Patricia. Bicycles, Bangs, and Bloomers: The New Woman in the Popular Press. Lexington: UP of Kentucky, 1990.

McCracken, Scott. "Stages of Sand and Blood: The Performance of Gendered Subjectivity in Olive Schreiner's Colonial Allegories.” Women's Writing 3.3 (1996): 231-42.

“Modern Mannish Maidens.” Blackwood's, Feb. 1890: 252-64.

Mezei, Kathy, ed. Ambiguous Discourse: Feminist Narratology and British Women Writers. Chapel Hill/ London: U of North Carolina P, 1996.

Murphy, Patricia. Time is of the Essence. New-York: State U of New-York P, 2001.

Nelson, Carolyn Christensen. Ed. A New Woman Reader: Fiction, Articles, Drama of the 1890s.

Peterborough: Broadview, 2001.

Parkin-Gounelas, Ruth. Fictions of the Female Self: Charlotte Brontë, Olive Schreiner, Katherine Mansfield. New-York: St Martin's, 1991.

Pykett, Lyn. The "Improper" Feminine: The Women's Sensation Novel and the New Woman Writing. NewYork/London: Routledge, 1992.

Quilligan, Maureen. The Language of Allegory: Defining the Genre. Ithaca/London: Cornell UP, 1979. Richardson, Angelique. Love and Eugenics in the Late Nineteenth Century: Rational Reproduction and the New Woman. Oxford: Oxford UP, 2003.

---. Ed. Women Who Did: Stories by Men and Women 1890-1914. London: Penguin, 2002.

Roth-Pierpont, Claudia. Passionate Minds: Women Rewriting the World. New-York: Knopf, 2001.

Schreiner, Olive. Dreams: Three Works. Dreams, Dream Life and Real Life and Stories, Dreams and Allegories. 1891. 1923. Ed. Elizabeth Jay. Birmingham: Birmingham UP, 2003.

---. From Man to Man. 1926. London: Virago, 1982.

---. Letters 1871-99. Ed. Richard Rive. Cape Town: Philip, 1987.

---. Rêves. Translation by Henriette Mirabaud Thorens. Preface by Marie Diémer. Illustrations by Carlos Schwabe. Paris: Flammarion, 1912.

---. The Story of an African Farm. 1883. Ed. Joseph Bristow. Oxford: Oxford UP, 1998.

---. Woman and Labour. 1911. London: Virago, 1988.

Showalter, Elaine. A Literature of their Own: From Charlotte Brontë to Doris Lessing. London: Virago, 1977.

---. Sexual Anarchy: Gender and Culture at the Fin de Siècle. New-York: Viking Penguin, 1990.

Somner, Roy. “'Contextualism' Revisited: A Survey (and Defence) of Postcolonial and Intercultural Narratologies." Journal of Literary Theory 1:1 (2007) 61-79.

Stanley, Liz. Imperialism, Labour and the New Woman: Olive Schreiner's Social Theory. Durham: Sociologypress, 2002.

Stubbs, Patricia. Women and Fiction: Feminism and the Novel 1880-1920. Brighton: Harvester, 1979. Suleiman, Susan Rubin. Authoritarian Fictions: The Ideological Novel as a Literary Genre. New-York: Columbia UP, 1983.

Thompson, N. Diane. Ed. Victorian Women Writers and the Woman Question. Cambridge: Cambridge UP, 2000. 
Warhol, Robyn R. Gendered Interventions: Narrative Discourse in the Victorian Novel. New Brunswick: Rutgers UP, 1989.

Warhol Robin and Susan S. Lanser. Ed. Narrative Theory Unbound: Queer and Feminist Interventions. Columbus: Ohio State UP, 2015.

Wilde, Oscar. The Picture of Dorian Gray. 1891. New-York: Norton, 1988.

\section{NOTES}

1. Scholarship on Schreiner includes Berkman; Bjørhovde; Brandon (1-94); First and Scott; Hackett; Heilmann; Horton; Kucich; Roth-Pierpont; Stanley.

2. The term was coined by Sarah Grand in an essay entitled "The New Aspect of the Woman Question" published in the North American Review in March 1894 (Nelson 141-46). Recent scholarship on New Woman Fiction includes Ardis; Heilmann; Kranidis; Ledger; Mangum; Marks; Murphy; Pykett; Richardson (2002); Thompson. Short anthologies include Nelson; Richardson (2002).

3. For this specific question in Schreiner's works, see Heilmann 119-38; Chrisman 1990; McCracken. Critics have been divided over the merits of Schreiner's allegories. While Elaine Showalter called them "sentimental allegories in the most nauseating fin-de-siècle style" (197), Patricia Stubbs wrote that "Schreiner's favourite and most successful vehicle is not realist fiction at all. She works best in parables, allegories and dream visions, in fact in all narrative methods of religious teaching. Her style, her turn of phrase is often close to the rhythm and cadence of the King James Bible, and she seems to draw on Bunyan - in her use of symbol and allegory, and in the texture and sound of her prose." (115)

4. Besides these, Schreiner also included allegories in her fragmentary introduction to Mary Wollstonecraft's Vindication of the Rights of Women (First and Scott 288), and wrote a political allegory entitled Trooper Peter of Mashonaland (1897). Laura Chrisman writes that "[t]he only way Schreiner can recuperate Wollstonecraft's feminism is by allegorizing it, in a sense." (133)

5. In 1912, she resigned as Vice-President of the Women's Enfranchisement League because, while granting suffrage to women, it still excluded black women from the vote (First \& Scott 261-263). See Olive Schreiner: Ruth Alexander MSC 26/2.1.29. The Olive Schreiner Letters on line.

6. Schreiner's theoretical works include her "papers on woman" which she later collected into what she called her "sex book" (Letters 205), Woman and Labour (1911).

7. This unflattering verb is used six times (From Man 182, 184, 185, 186).

8. "What began as a focus on the impact of culturally constructed gender upon the form and reception of narrative texts has broadened to feminist narratologies that recognize race, sexuality, nationality, class, and ethnicity as well as gender in formulating their theoretical and analytical projects." (Warhol and Lanser 6)

9. Schreiner broke with the Christian faith following the death of her sister Ellie when she was nine but, as Ruth First and Ann Scott argue in their biography, Schreiner rejected the Church rather than Christian values and, when she revisited the New Testament to bend it to her own philosophical and political uses, she remained true to the traditional message of Christian love (54-55).

10. Citations from Dreams refer to Elizabeth Jay's 2003 edition.

11. "In more realistic literature, there have been spurts of interest in the female hero (...). Literature that moves away from realism and toward myth, however, literature that approaches the schematization and stylization of myth or archetype, tends to be dominated by a male hero." (Little 17)

12. The opening of "In a Ruined Chapel" is told impersonally with a second-person point of view. 
13. "[Olive Schreiner's] most notable contribution to first-wave feminism was her conceptualization of the essential correlation between the imposition of gender, race and class hegemonies, an insight which resulted in her firm commitment to universal human rights." (Heilmann 123)

14. Susan Lanser drew the following distinction between her use of the words "sex" and "gender": "I will use the term 'sex' to designate the formal identification of a represented human entity as male or female. I will use 'gender' to designate characteristics constructed in and by texts that implicate - but do not prove - a male or female identity by drawing on cultural codes that conventionally signify masculinity and femininity" (Mezei 251-52).

15. The translation of Dreams into French (1912) gives us some insight into the question of readers' attitudes to the narrator's gender. Translating the stories into French sometimes requires deciding on the narrator's gender within the story's first few lines $(60,101,109)$. Henriette Mirabaud Thorens assumed the narrator was female throughout, and used neutral forms to translate incidental masculine markers. However, Carlos Schwabe's illustrations worked towards re-establishing the balance since he seems to have assumed that the narrator was male. Marie Diémer prefaced the collection by contextualizing it in the male English literary tradition.

16. In a note, Heilmann added: "Like myself, Laura Chrisman infers the narrator to be female, while McCracken reads her/his lack of an unambiguously defined gender as an indication of the 'undecided nature of identity in culture in contrast with the overdetermined conditions that weigh down woman as actor' inside the frame." (263)

17. "In the dark one night I lay upon my bed. I heard the policeman's feet beat on the pavement; I heard the wheels of carriages roll home from houses of entertainment; I heard a woman's laugh below my window-and then I fell asleep. And in the dark I dreamt a dream. I dreamt God took my soul to Hell." (33)

18. These quotations are taken from the first version published in Lippincott's Monthly Magazine in July 1890.

19. "In the streets below, men and women streamed past by hundreds; I heard the beat of their feet on the pavement. Men on their way to business; servants on errands; boys hurrying to school; weary professors pacing slowly the old street; prostitutes, men and women, dragging their feet wearily after last night's debauch; artists with quick, impatient footsteps; tradesmen for orders; children to seek for bread. I heard the stream beat by. And at the alley's mouth, at the street corner, a broken barrel-organ was playing; sometimes it quavered and almost stopped, then went on again, like a broken human voice." (46)

20. "One day we sit there and look up at the blue sky, and down at our fat little knees; and suddenly it strikes us, Who are we? This $I$, what is it? We try to look in upon ourself, and ourself bears back upon ourself. Then we get up in great fear and run home as hard as we can. (...) we are twisting, twirling, trying to make an allegory. (...) Do not ask us how we make our dream tally with facts; the glory of a dream is this - that it despises facts, and makes its own. Our dream saves us from being mad; that is enough." (Schreiner The Story 103, 107, 109)

21. Gerd BjØrhovde notes that besides using a male pseudonym when publishing The Story of an African Farm, Schreiner also refers to herself as "he" in the preface to the second edition (87).

22. Since Alladeen is said to "bur[y] her wonderful stone", Joseph Bristow calls it "a confused reference to 'Aladdin, or The Wonderful Lamp' from The Arabian Nights" (Schreiner 1998, 275).

23. "My great fault as a writer is that I cannot bear to re-touch, even to reread anything when once I have written it. I have three novels, two other books, a whole box of dreams, all dashed off and then never looked at again." (Letters 148)

24. See "Manly Women"; "Modern Mannish Maidens"; Linton. See also Sarah Grand, "The New Aspect of the Woman Question" (Nelson 141-46). For a discussion of the evolutionary turn taken by discourses of masculinization and effeminacy in the late nineteenth century, see Hamilton; Marks (176-78). 


\section{ABSTRACTS}

The South-African essayist and novelist Olive Schreiner wrote allegories which were treasured by early twentieth-century feminists, who turned to them for inspiration and comfort. In Dreams (1890), Schreiner denounced the arbitrariness of man's domination over woman, invited women to try to achieve both Freedom and Love, and looked forward to a state of gender equality. Schreiner's allegories are a good place to start an inquiry into the ways in which narratological practices can challenge stereotyped perceptions of gender. The first-person narrator, who is our substitute in many of her stories, is the source of the hermeneutic process at the core of the allegory. The reader's conjectures are rendered more complex by the ambivalence of this narrator's gender. Schreiner's prophet/ess delivers a pragmatic truth, depending on the sexual identity which the reader attributes to him/her in context. Gender neutral first-person narration allowed Schreiner to tell certain stories from a gender-free perspective, or created gender leeway which allowed meaning to proliferate.

La romancière et essayiste Olive Schreiner est l'auteure d'allégories qui ont inspiré et soutenu de nombreuses penseuses et militantes féministes au début $\mathrm{du} \mathrm{XX}^{\mathrm{e}}$ siècle. Dans Rêves (1890), elle dénonce la domination injustifiée de l'homme sur la femme, encourage les femmes à conquérir la Liberté et l'Amour et pense l'état d'égalité des sexes. Les allégories de Schreiner constituent un corpus de choix pour étudier comment les pratiques narratives peuvent influer sur la représentation du genre. Le narrateur à la première personne, qui est notre mise-en-abyme dans le texte, est à l'origine du processus herméneutique à l'œuvre dans l'allégorie. Notre interprétation du texte est compliquée par l'identité sexuelle incertaine de ce narrateur. La Vérité dont il est question dans les allégories est une vérité pragmatique, qui varie selon le sexe que le lecteur attribue au narrateur en contexte. La narration à la première personne, où le genre n'est pas marqué en anglais, permet à Schreiner de parler depuis une perspective "neutre ", à moins qu'il ne s'agisse de jeter le trouble dans le genre de façon à élargir les lectures possibles du texte.

\section{INDEX}

Keywords: allegory, feminism, gender, narratology

Mots-clés: allégorie, féminisme, genre, narratologie

\section{AUTHORS}

\section{NATHALIE SAUDO-WELBY}

Maître de conférences

Université de Picardie Jules-Verne

nathalie.saudo@u-picardie.fr 